This PDF is a selection from a published volume from the National Bureau of Economic Research

Volume Title: Reforming the Welfare State: Recovery and Beyond in Sweden

Volume Author/Editor: Richard B. Freeman, Birgitta Swedenborg and Robert Topel, editors

Volume Publisher: The University of Chicago Press

Volume ISBN: 0-226-26192-1

Volume URL: http://www.nber.org/books/free05-1

Conference Dates: September 30-October 1, 2005

Publication Date: February 2010

Chapter Title: Front matter, table of contents, acknowledgments

Chapter Author: Richard B. Freeman, Birgitta Swedenborg, Robert H. Topel

Chapter URL: http://www.nber.org/chapters/c12009

Chapter pages in book: (cover - xii) 
National Bureau of Economic Research

\section{Reforming the}

Welfare State

RECOVERY

AND BEYOND

IN SWEDEN

Edited by Richard B. Freeman,

Birgitta Swedenborg, and Robert H. Topel 
This PDF is a selection from a published volume from the National Bureau of Economic Research

Volume Title: Reforming the Welfare State: Recovery and Beyond in Sweden

Volume Author/Editor: Richard B. Freeman, Birgitta Swedenborg and Robert Topel, editors

Volume Publisher: The University of Chicago Press

Volume ISBN: 0-226-26192-1

Volume URL: http://www.nber.org/books/free05-1

Conference Dates: September 30-October 1, 2005

Publication Date: February 2010

Chapter Title: Front matter, table of contents, acknowledgments

Chapter Author: Richard B. Freeman, Birgitta Swedenborg, Robert H. Topel

Chapter URL: http://www.nber.org/chapters/c12009

Chapter pages in book: (cover - xii) 
Reforming the Welfare State 
A National Bureau

of Economic Research

Conference Report 


\section{Reforming the Welfare State Recovery and Beyond in Sweden}

Edited by Richard B. Freeman, Birgitta Swedenborg, and Robert Topel

The University of Chicago Press

Chicago and London 
Richard B. Freeman is the Herbert Ascherman Professor of Economics at Harvard University and a research associate at the National Bureau of Economic Research. Birgitta Swedenborg is an economist and former vice president and research director of the Center for Business and Policy Studies (SNS) in Stockholm, Sweden. Robert Topel is the Isidore Brown and Gladys J. Brown Professor in Urban and Labor Economics at the Booth Graduate School of Business, University of Chicago, and a research associate of the National Bureau of Economic Research.

The University of Chicago Press, Chicago 60637

The University of Chicago Press, Ltd., London (C) 2010 by the National Bureau of Economic Research All rights reserved. Published 2010

Printed in the United States of America

$\begin{array}{lllllllllllllll}19 & 18 & 17 & 16 & 15 & 14 & 13 & 12 & 11 & 10 & 1 & 2 & 3 & 4 & 5\end{array}$

ISBN-13: 978-0-226-26192-8 (cloth)

ISBN-10: 0-226-26192-1 (cloth)

Library of Congress Cataloging-in-Publication Data

Reforming the welfare state : recovery and beyond in Sweden / edited by Richard B. Freeman, Birgitta Swedenborg, and Robert Topel. p. cm.

Includes bibliographical references and index.

ISBN-13: 978-0-226-26192-8 (alk. paper)

ISBN-10: 0-226-26192-1 (alk. paper)

1. Sweden-Economic policy. 2. Sweden-Economic conditions-1945-3. Manpower policy-Sweden. 4. Labor market-Sweden. 5. Welfare state-Sweden. I. Freeman, Richard B. (Richard Barry), 1943- II. Swedenborg, Birgitta, 1941- III. Topel, Robert H.

HC375.R422 2010

$330.9485-\mathrm{dc} 22$

2009024336

(2) The paper used in this publication meets the minimum requirements of the American National Standard for Information Sciences-

Permanence of Paper for Printed Library Materials, ANSI Z39.48-1992. 


\section{National Bureau of Economic Research}

\section{Officers}

John S. Clarkeson, chairman

Kathleen B. Cooper, vice-chairman

James M. Poterba, president and chief executive officer

Robert Mednick, treasurer
Kelly Horak, controller and assistant corporate secretary

Alterra Milone, corporate secretary

Gerardine Johnson, assistant corporate secretary

\section{Directors at Large}

Peter C. Aldrich

Elizabeth E. Bailey

Richard B. Berner

John H. Biggs

John S. Clarkeson

Don R. Conlan

Kathleen B. Cooper

Charles H. Dallara

George C. Eads
Jessica P. Einhorn

Mohamed El-Erian

Jacob A. Frenkel

Judith M. Gueron

Robert S. Hamada

Karen N. Horn

John Lipsky

Laurence H. Meyer

Michael H. Moskow
Alicia H. Munnell

Rudolph A. Oswald

Robert T. Parry

James M. Poterba

John S. Reed

Marina v. N. Whitman

Martin B. Zimmerman

\section{Directors by University Appointment}

George Akerlof, California, Berkeley

Jagdish Bhagwati, Columbia

Glen G. Cain, Wisconsin

Ray C. Fair, Yale

Franklin Fisher, Massachusetts Institute of Technology

Mark Grinblatt, California, Los Angeles

Saul H. Hymans, Michigan

Marjorie B. McElroy, Duke
Joel Mokyr, Northwestern

Andrew Postlewaite, Pennsylvania

Uwe E. Reinhardt, Princeton

Nathan Rosenberg, Stanford

Craig Swan, Minnesota

David B. Yoffie, Harvard

Arnold Zellner (Director Emeritus), Chicago

\section{Directors by Appointment of Other Organizations}

Jean-Paul Chavas, Agricultural and Applied Economics Association

Gail D. Fosler, The Conference Board

Martin Gruber, American Finance Association

Timothy W. Guinnane, Economic History Association

Arthur B. Kennickell, American Statistical Association

Thea Lee, American Federation of Labor and Congress of Industrial Organizations
William W. Lewis, Committee for Economic Development

Robert Mednick, American Institute of Certified Public Accountants

Angelo Melino, Canadian Economics Association

Harvey Rosenblum, National Association for Business Economics

John J. Siegfried, American Economic Association

\section{Directors Emeriti}

Andrew Brimmer

Carl F. Christ

George Hatsopoulos

Lawrence R. Klein
Franklin A. Lindsay

Paul W. McCracken

Peter G. Peterson

Richard N. Rosett
Eli Shapiro

Arnold Zellner 


\section{Relation of the Directors to the Work and Publications of the National Bureau of Economic Research}

1. The object of the NBER is to ascertain and present to the economics profession, and to the public more generally, important economic facts and their interpretation in a scientific manner without policy recommendations. The Board of Directors is charged with the responsibility of ensuring that the work of the NBER is carried on in strict conformity with this object.

2. The President shall establish an internal review process to ensure that book manuscripts proposed for publication DO NOT contain policy recommendations. This shall apply both to the proceedings of conferences and to manuscripts by a single author or by one or more coauthors but shall not apply to authors of comments at NBER conferences who are not NBER affiliates.

3. No book manuscript reporting research shall be published by the NBER until the President has sent to each member of the Board a notice that a manuscript is recommended for publication and that in the President's opinion it is suitable for publication in accordance with the above principles of the NBER. Such notification will include a table of contents and an abstract or summary of the manuscript's content, a list of contributors if applicable, and a response form for use by Directors who desire a copy of the manuscript for review. Each manuscript shall contain a summary drawing attention to the nature and treatment of the problem studied and the main conclusions reached.

4. No volume shall be published until forty-five days have elapsed from the above notification of intention to publish it. During this period a copy shall be sent to any Director requesting it, and if any Director objects to publication on the grounds that the manuscript contains policy recommendations, the objection will be presented to the author(s) or editor(s). In case of dispute, all members of the Board shall be notified, and the President shall appoint an ad hoc committee of the Board to decide the matter; thirty days additional shall be granted for this purpose.

5. The President shall present annually to the Board a report describing the internal manuscript review process, any objections made by Directors before publication or by anyone after publication, any disputes about such matters, and how they were handled.

6. Publications of the NBER issued for informational purposes concerning the work of the Bureau, or issued to inform the public of the activities at the Bureau, including but not limited to the NBER Digest and Reporter, shall be consistent with the object stated in paragraph 1. They shall contain a specific disclaimer noting that they have not passed through the review procedures required in this resolution. The Executive Committee of the Board is charged with the review of all such publications from time to time.

7. NBER working papers and manuscripts distributed on the Bureau's web site are not deemed to be publications for the purpose of this resolution, but they shall be consistent with the object stated in paragraph 1 . Working papers shall contain a specific disclaimer noting that they have not passed through the review procedures required in this resolution. The NBER's web site shall contain a similar disclaimer. The President shall establish an internal review process to ensure that the working papers and the web site do not contain policy recommendations, and shall report annually to the Board on this process and any concerns raised in connection with it.

8. Unless otherwise determined by the Board or exempted by the terms of paragraphs 6 and 7 , a copy of this resolution shall be printed in each NBER publication as described in paragraph 2 above. 


\section{Contents}

Acknowledgments $\quad$ xi

Introduction 1

Richard B. Freeman, Birgitta Swedenborg, and Robert Topel

1. Searching for Optimal Inequality/Incentives

Anders Björklund and Richard B. Freeman

2. Policies Affecting Work Patterns and Labor Income for Women

Ann-Sofie Kolm and Edward P. Lazear

3. Wage Determination and Employment in

Sweden Since the Early 1990s: Wage Formation

in a New Setting

Peter Fredriksson and Robert Topel

4. Labor Supply, Tax Base, and Public Policy

in Sweden

Thomas Aronsson and James R. Walker

5. Did Active Labor Market Policies Help Sweden

Rebound from the Depression of the Early 1990s?

Anders Forslund and Alan Krueger

6.

How Sweden's Unemployment Became More

Like Europe's

Lars Ljungqvist and Thomas J. Sargent 
7. Economic Performance and Market Work Activity in Sweden after the Crisis of the Early 1990s

Steven J. Davis and Magnus Henrekson

8. Competition, Regulation, and the Role of Local

Government Policies in Swedish Markets

Stefan Fölster and Sam Peltzman

9. What Have Changes to the Global Markets for

Goods and Services Done to the Viability of the

Swedish Welfare State?

Edward E. Leamer

Contributors

Author Index

Subject Index 
This volume is dedicated to our late friend and colleague Sherwin Rosen, who contributed greatly to our original study and whose insights on the Swedish recovery from crisis we sadly miss. 



\section{Acknowledgments}

The contributions in this volume are the result of a research project on the Swedish welfare state organized jointly by the Center for Business and Policy Studies (SNS) in Sweden and the National Bureau of Economic Research (NBER) in the United States. Most contributions are authored jointly by an American and a Swedish economist associated with the NBER and SNS, respectively.

The SNS is a private, nonpartisan, nonprofit organization with the aim of promoting research on economic and social issues of importance to public decision making and of making it readily available to a broad audience. As an organization, SNS does not take a stand on policy matters.

The research for this volume has been made possible by financial support, first and foremost from the Jan Wallander and Tom Hedelius Foundation and the Tore Browald Foundation. Support has also been received from the Sven and Dagmar Salén Foundation and the Bank of Sweden Tercentenary Foundation. 
